\title{
Increasing Community Awareness and Intention in Encouraging The Growth of Cash Waqf
}

\author{
Muhammad lqbal \\ Perbanas Institute \\ email: iqbal@perbanas.id

\section{Prameswara Samofa Nadya} \\ Perbanas Institute \\ email: psn2979@gmail.com
}

\section{Saripudin}

Perbanas Institute

email: iip@perbanas.id

\section{Puji Hadiyati \\ Perbanas Institute email: puji.hadiyati@perbanas.id}

\begin{abstract}
This study aims to identify factors that determine the awareness, intention and decision of the Indonesian people to cash waqf. Data collection techniques using purposive sampling with PLS (Partial Least Squared) method as a data analysis tool in this study includes a path analysis model. The results obtained show that the social environment and understanding affect one's awareness and interest in cash waqf. The emergence of awareness and intention will encourage the person to carry out cash waqf. While the promotion of cash waqf does not affect awareness and intentions which in the end will not encourage someone to cash waqf.
\end{abstract}

Keywords: cash waqf; understanding; social environment; awareness; intention

Abstrak: Penelitian ini bertujuan mengidentifikasi faktor-faktor yang menentukan kesadaran, minat dan keputusan masyarakat Indonesia untuk berwakaf uang. Teknik penggumpulan data menggunakan purposive sampling dengan metode PLS (Partial Least Squared) sebagai alat analisis data yang dalam penelitian ini memuat model analisis jalur. Hasil yang diperoleh menunjukkan bahwa lingkungan sosial dan pemahaman mempengaruhi kesadaran dan minat seseorang akan wakaf uang. Munculnya kesadaran dan minat akan mendorong orang tersebut untuk melaksanakan wakaf uang. Sedangkan promosi tentang wakaf uang tidak mempengaruhi kesadaran dan minat yang pada akhirnya tidak akan mendorong seseorang untuk berwakaf uang.

Kata Kunci: wakaf uang; pemahaman; lingkungan sosial; kesadaran; minat

Economica: Jurnal Ekonomi Islam - Volume 10, Nomor 1 (2019) 
Muhammad Iqbal, Prameswara Samofa Nadya, Saripudin, Puji Hadiyati

\section{Introduction}

Waqf as a form of philanthropic configuration in Islam has an important role in minimizing community economic inequality, alleviating poverty and minimizing unemployment (Uyun, 2015). This happens when waqf property is used as an instrument of economic empowerment of the people, not only as an asset that has worship value but does not have social and economic value. If waqf is productive, it is not only valuable in terms of divinity but also has social value in order to improve the welfare of society.

Empowerment of waqf for social and economic activities or what is commonly referred to as productive waqf is not new. Empowerment of productive waqf has existed since the time of the Prophet Muhammad and the heyday of Islam, it's just that the majority of Muslims today view waqf are limited to the form of land or property used for religious activities only. Some people in Indonesia still place waqf property on things that are silent rather than yielding or productive (Kasdi, 2016).

The use of waqf property in productive matters is caused by many factors. Starting from the low awareness and intention of the community towards waqf itself (Kasdi, 2016; Muntaqo, 2015), lack of professionalism in managing waqf (Huda, Rini, Mardoni, Hudori, \& Anggraini, 2017; Muntaqo, 2015), up to the lack of the government's role in optimizing the potential of waqf (Huda et al., 2017; Muntaqo, 2015; Syamsir, 2015). If we reflect on the experience of other Muslim countries, such as Egypt, Arabia, Turkey, Malaysia and Bangladesh which have succeeded in optimizing productive waqf (Hasan \& Rahmawati, 2011; Nilna Fauzah, 2015) Indonesia should be able to do it too.

The productive waqf itself has been outlined in Law No. 41 of 2004 which is one of the instruments in building the socio-economic life of Muslims. The presence of this waqf law is a momentum for the empowerment of waqf productively, because it contains a comprehensive 
Increasing Community Awareness and Intention in Encouraging ...

understanding and management pattern of empowering the potential of waqf in a modern way. The Act also describes the Cash Waqf as an option for people who want to be a representative so that not only those who have excess assets can be represented, but for those who are mediocre property can also be representative. Previously the Indonesian Ulema Council (MUI) had also issued a fatwa on cash waqf on May 11, 2002 about the possibility of cash waqf and other securities.

Until 2018, according to the Chairperson of the Public Relations, Socialization and Literacy Division of the Indonesian Waqf Board (BWI) Atabik Lutfi - the potential for cash waqf in Indonesia could reach Rp 180 trillion, with its realization currently only reaching Rp 400 billion (Fadhilah \& Aminah, 2018). This indicates that there is still a large gap between the existing potential and the realization of cash waqf collection from the community.

The low community participation in cash waqf programs is caused by many things, starting from the lack of information about cash waqf (Adeyemi, Ismail, \& Hassan, 2016; Fanani, 2011; Ilyas, 2014), knowledge and understanding of cash waqf (Adeyemi et al., 2016; Dahlan, 2014; Rahmawati, 2013), socio-cultural conditions (Adeyemi et al., 2016), the low competence of Nazhir as waqf manager (Fanani, 2011; Rahmawati, 2013), to the lack of government role in promoting cash waqf programs (Siswantoro \& Rosdiana, 2016). In addition, some of the institutions designated in collecting cash waqf were also not optimal in collecting public funds (Furqon, 2011).

This research does not discuss all the problems that exist about waqf as explained above. The scope of the study is only on the issue of raising cash waqf funds from the community. Limitation of the object of research is also in cash waqf, not all types of waqf. This is done because the potential of such large cash waqf and the development of cash waqf both directly and indirectly will contribute to the welfare of their community at large (Mohsin, 2013). Therefore, the results of this study are expected to be useful for the

Economica: Jurnal Ekonomi Islam - Volume 10, Nomor 1 (2019) 
collectors of cash waqf funds, such as the Islamic Financial Institution of Islamic Cash Waqf Collectors (LKS-PWU) and other cash waqf collection agencies, in order to be able to identify the factors that influence the community's decision to become an endowment.

This study aims to design an effective approach in raising cash waqf funds. It is suspected that promotion, social environment and understanding influence people's awareness, intention and decisions in representing cash waqf. Identification of the factors that influence people's decisions in the representation of cash waqf is expected to be the focus of a strategy in collecting cash waqf funds.

The similarity of this study with the research of Adeyemi et al. (2016); Fatah, Mansor, Ripain, \& Endut (2017); Harun, Rashid, Murat, \& Yaakub (2016) are in the identification of the factors that influence people's awareness in having cash waqf. But in general the method of analysis used in this study is different from the previous three studies although both use a quantitative approach. While other studies such as Ibrahim, Amir, \& Masron, (2013); Mu'alim \& Abdurrahman (2014); Syafiq (2016) places more emphasis on the role of cash waqf itself, not trying to analyze its collection.

\section{Literature review}

As one form of worship that is recommended for Muslims, waqf have virtues that never break their merits even though the person who is representative (waqif) has died (Hasan, 2010). According to the Republic of Indonesia Law No. 41/2004, Waqf is interpreted as a legal act of waqif to separate and/or surrender a portion of his property to be used forever or for a certain period of time in accordance with the interests of religious purposes and/or general welfare according to sharia. So waqf can be said as an action taken by holding assets and giving away benefits continuously to the general public both for religious and social purposes (Aziz \& Yusof, 2014). 
Increasing Community Awareness and Intention in Encouraging ...

Waqf has the nature that the value of property is always eternal, then it is proper for waqf to have more functions than other assets, such as having socio-economic benefits, in addition to divine benefits. Today waqf have begun to be looked at for professional-productive empowerment. The professional aspects include management, Nazhir's human resources, business partnership patterns, to the form of waqf objects which are not only in the form of immovable assets such as money, shares and other securities (Haryanto, 2013).

Cash waqf as explained in Law No. 41 of 2004 is translated as cash waqf with the object of waqf money. Cash Waqf based on Indonesian MUI fatwa dated May 11, 2002 is waqf by a person, group of people or institutions or legal entities in the form of cash, including securities. Cash waqf is jawaz (permissible) and is only distributed for things that are permitted by Islamic law. The principal value of money must be guaranteed for its sustainability, must not be sold, granted or bequeathed. Thus, cash waqf can be done by anyone even though the funds are limited, thus giving way to the Muslims even though not from the rich (Haryanto, 2013).

The practice of collecting cash waqf in Indonesia is mostly carried out by the Amil Zakat Institution (LAZ), for example such as the Community Care Justice Post (PKPU), Baitul Mal Muamalat (BMM), the Fast Action Response (ACT) and LAZNAS or LASDA. There are also institutions that specifically manage waqf such as the Indonesian Waqf Tube (TWI) and the Indonesian Waqf Board (BWI). BWI itself is an independent institution formed under Law No. 41 of 2004. In terms of collecting waqf funds, BWI cooperates with Sharia Financial Institutions (LKS) for Receiving Money Waqf (PWU). This is done because one of the reasons is the extensive LKS network. Until the end of 2015, fifteen LKS-PWU had become BWI partners (Hastuti, 2018).

The collection of cash waqf funds so far has been done naturally as other social fund raising programs. Some cash waqf collection agencies do not specifically have a collection program. Most of the focus of institutions for

Economica: Jurnal Ekonomi Islam - Volume 10, Nomor 1 (2019) 
raising cash waqf funds, most of which also act as managers (nazir) on the distribution or allocation of cash waqf funds. Currently the distribution or empowerment program for cash waqf funds varies greatly, ranging from the health sector, education to community economic empowerment (Fanani, 2011).

Unlike the cash waqf fund-raising institutions which also act as managers, the LKS-PWU only acts as cash waqf fund-raising institutions. The results of this collection will be collected by BWI as the manager. Some of the problems encountered by LKS-PWU in collecting cash waqf funds are, among others, relatively limited information dissemination, the absence of special units to handle them to the lack of public understanding of cash waqf (Furqon, 2011).

In addition to its utilization and management, the collection of cash waqf funds should also receive special attention. Waqf funds can be collected optimally from the community if there is awareness and intention from the community. Awareness can grow from knowledge and understanding. After awareness comes, it is hoped that intention will emerge (Adeyemi et al., 2016).

According to Kotler \& Keller (2015) awareness on behalf of the product/brand (in this case is cash waqf) makes individuals have the ability to identify brands under different conditions. When a brand is often seen, for example in advertisements and other interactions, consumers see the brand as something that is familiar and popular. Meanwhile, the intention itself is defined as how likely it is that individuals from one brand to another.

Decisions made by each individual (consumer) are actually a collection of a number of decisions consisting of seven components, namely: type of product, product form, brand, sales, number of products, time of purchase and method of payment. While the stage of the decision making process consists of five stages, namely: introduction of needs, information search, 
alternative evaluations, purchasing decisions and post-purchase behavior (Kotler \& Keller, 2015).

Access to public information also greatly influences people's knowledge and understanding of cash waqf (Adeyemi et al., 2016; Efrizon, 2008). Socialization, education and promotion programs are one way to provide adequate information about the cash waqf program. Those who have sufficient information about cash waqf will have good knowledge and understanding, so that eventually they have the awareness to do cash waqf (Adeyemi et al., 2016).

Community behavior which includes knowledge, understanding, preferences and social environment are some things that are considered to influence one's decision to make a cash waqf (Adeyemi et al., 2016; Yunimar, 2015). Lack of public understanding of cash waqf causes awareness to represent even lower. The social environment, such as family, religious activity groups, and the surrounding environment has an impact on the information received by the community about waqf, thus affecting the decision to cash waqf.

Figure 1. Critical Framework

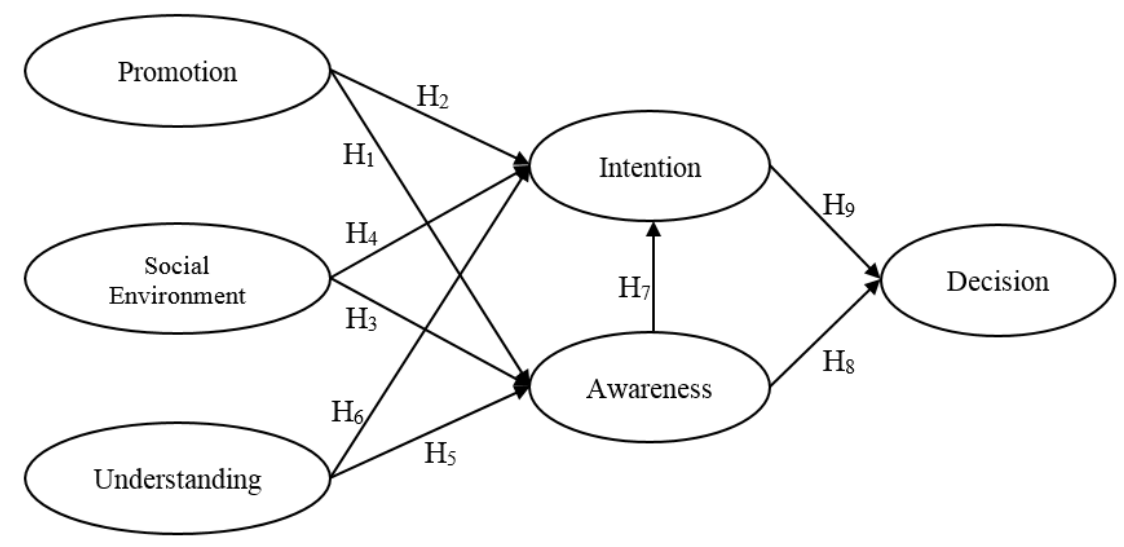

Economica: Jurnal Ekonomi Islam - Volume 10, Nomor 1 (2019) http://journal.walisongo.ac.id/index.php/economica 
Muhammad Iqbal, Prameswara Samofa Nadya, Saripudin, Puji Hadiyati

From the above explanations, the following hypotheses can be formulated:

H1 : Promotion affects a person's awareness of cash waqf.

H2 : Promotion affects one's intention to cash waqf.

H3 : Social environment influences one's awareness to cash waqf.

H4 : Social environment influences one's intention to cash waqf.

H5 : Understanding influences one's awareness to cash waqf.

H6 : Understanding affects one's intenton to cash waqf.

H7 : Awareness affects one's intention to cash waqf.

H8 : Awareness affects one's decision to cash waqf.

H9 : Intention influences one's decision to cash waqf.

\section{Methods}

This study uses a quantitative design which is a systematic study of parts and phenomena and their relationships (McMillan \& Schumacher, 2009). The purpose of quantitative research is to develop and use models, theories and or hypotheses relating to natural phenomena (Creswell, 2013).

This type of research data is primary data with the object of research of Muslims in Indonesia. Data were collected using a questionnaire instrument. The sampling technique uses probability sampling, which can be determined from the number of known populations. The sample selection with this technique is based on the researchers' assessment that the respondent is the best party to be used as the sample of his research (Sekaran \& Bougie, 2013). The location of the study as well as the limitation of the study population are spread across 17 provinces with 3 main provinces, namely DKI Jakarta, West Java and Banten.

The research model built from the findings of several previous studies is summarized in Figure 1. Where promotion, understanding and social 
environment act as exogenous variables for awareness and intention. It is suspected that the promotion of cash waqf, one's understanding of cash waqf and the social environment affects the awareness and intention for cash waqf (Adeyemi et al., 2016; Fanani, 2011; Furqon, 2011; Muntaqo, 2015). While awareness is thought to affect one's intention and decision to cash waqf. While intention is also thought to influence a person's decision to make a cash waqf and also as a mediating variable for awareness, promotion, understanding and social environment of one's decision to cash waqf (Adeyemi et al., 2016; Mulyono, 2016).

Data analysis technique used Structural Equation Modeling (SEM) which aims to see the relationship in the form of paths between the variables that exist. By knowing the flow of relationships between research variables, it is expected to identify which variables determine a person's decision for cash waqf. The SEM model used is PLS (Partial Least Squared), because this study focuses more on predictions in order to develop theories than test existing theories. In addition, the ease of fulfilling the number of samples owned by PLS is also a reason for researchers to choose them.

PLS is a powerful analysis method and soft modeling because it eliminates OLS (Ordinary Least Squares) regression assumptions, such as data must be normally distributed multivariately and there is no multicollinearity problem between exogenous variables (Wold, 1982). Besides being used to explain the presence or absence of relationships between latent variables, PLS can also be used to confirm theories (Chin \& Newsted, 1999).

PLS analysis consists of two sub-models, namely the measurement model and structural model. The measurement model (commonly called the outer model) shows how each block of indicators relates to its latent variable, while the structural model (commonly called the inner model) shows the relationship between latent variables based on substantive theory (Ghozali \& Latan, 2015).

Economica: Jurnal Ekonomi Islam - Volume 10, Nomor 1 (2019) 


\section{Results and Discussion}

The results of data collection carried out on 84 respondents who have used a cash waqf (waqif) have a profile as described in Table 1. Respondents who are waqif from cash waqf are dominated by women and most are those who are still in their productive age. In general, those who have done cash waqf have a formal undergraduate or postgraduate education and are dominated by the profession of private employees and teaching staff such as lecturers and teachers. This is one indication that the cash waqf is not so widely known to the general public, only those who have intense activities towards education and scientific development have ever had a cash waqf.

Table 1. Profile Waqif Cash Waqf

\begin{tabular}{lll}
\hline Characteristics & Category & Percentage \\
\hline Sex & Woman & $53.57 \%$ \\
\hline Age & Man & $46.43 \%$ \\
\hline & 17 - 25 years old & $16.67 \%$ \\
\hline & 26 - 35 years old & $20.24 \%$ \\
\hline Education & 36 - 50 years old & $51.19 \%$ \\
\hline & 51 - 60 years old & $10.71 \%$ \\
\hline & $>60$ years old & $1.19 \%$ \\
\hline & High school & $7.14 \%$ \\
\hline & Diploma & $3.57 \%$ \\
\hline Occupation & Bachelor & $34.52 \%$ \\
\hline & Postgraduate & $54.76 \%$ \\
\hline & College student & $10.71 \%$ \\
\hline
\end{tabular}


Increasing Community Awareness and Intention in Encouraging ...

\begin{tabular}{lll}
\hline Characteristics & Category & Percentage \\
\hline & Private employees & $30.95 \%$ \\
\hline Entrepreneur & $8.33 \%$ \\
\hline Teacher / Lecturer & $33.33 \%$ \\
\hline Professional & $5.95 \%$ \\
\hline Housewife & $3.57 \%$ \\
\hline Others & $1.19 \%$ \\
\hline$<3$ million rupiah & $17 \%$ \\
\hline $3-5$ million rupiah & $27 \%$ \\
\hline $5-10$ million rupiah & $33 \%$ \\
\hline 10 - 20 million rupiah & $7 \%$ \\
\hline 20 - 30 million rupiah & $10 \%$ \\
\hline 30 - 50 million rupiah & $2 \%$ \\
\hline$>50$ million rupiah & $4 \%$ \\
\hline
\end{tabular}

In general, the views of waqif (those who do cash waqf) towards the six variables are relatively the same, except the promotion variable. Variable understanding, social environment, awareness and intention of waqif towards cash waqf is relatively high. Even their decision for cash waqf was very high. Very high waqif decisions on cash waqf are very reasonable considering they are people who have decided to cash waqf. In contrast to other variables, promotion of cash waqf felt by waqif on average was very low. 
Muhammad Iqbal, Prameswara Samofa Nadya, Saripudin, Puji Hadiyati

Table 2. Research Variable Measurement Score

\begin{tabular}{|c|c|c|c|}
\hline Code & Indicator / Variable & Score & Scale \\
\hline PRO1 & Socialization of cash waqf to the community & 1.155 & Very low \\
\hline PRO2 & $\begin{array}{l}\text { Cash waqf information in various media, both print } \\
\text { and electronic }\end{array}$ & 1.321 & Very low \\
\hline PRO3 & Ease of getting information about cash waqf & 1.810 & Low \\
\hline PRO4 & $\begin{array}{l}\text { he discovery of an invitation / invitation to carry } \\
\text { out cash waqf }\end{array}$ & 1.214 & Very low \\
\hline PRO5 & $\begin{array}{l}\text { The ease of finding facilities to carry out cash waqf } \\
\text { was found }\end{array}$ & 1.905 & Low \\
\hline PRO6 & $\begin{array}{l}\text { he discovery of figures / scholars who campaigned } \\
\text { for cash waqf }\end{array}$ & 1.810 & Low \\
\hline \multirow[t]{2}{*}{ PRO7 } & A personal invitation was found to adjust cash waqf & 1.548 & Very low \\
\hline & Promotion & 1.538 & Very Low \\
\hline UND1 & $\begin{array}{l}\text { Cash waqf is one of the permissible forms of waqf } \\
\text { in Islamic jurisprudence }\end{array}$ & 4.107 & High \\
\hline UND2 & $\begin{array}{l}\text { Cash waqf has many uses compared to other types } \\
\text { of waqf }\end{array}$ & 3.845 & High \\
\hline UND3 & $\begin{array}{l}\text { Cash waqf in addition to the value of worship is } \\
\text { also of social \& economic value }\end{array}$ & 4.310 & Very high \\
\hline UND4 & $\begin{array}{l}\text { Cash waqf is an alternative to Islamic philanthropy } \\
\text { in reducing poverty }\end{array}$ & 4.380 & Very high \\
\hline UND5 & $\begin{array}{l}\text { Cash waqf is believed to be able to promote the } \\
\text { welfare of the wider community }\end{array}$ & 4.357 & Very high \\
\hline UND6 & $\begin{array}{l}\text { Cash waqf is a waqf instrument that has high } \\
\text { benefits }\end{array}$ & 4.321 & Very high \\
\hline UND7 & $\begin{array}{l}\text { Cash waqf has a double impact in driving economic } \\
\text { growth }\end{array}$ & 4.226 & Very high \\
\hline \multirow[t]{2}{*}{ UND8 } & $\begin{array}{l}\text { Cash waqf procedures are easy to understand by } \\
\text { the public }\end{array}$ & 3.702 & High \\
\hline & Understanding & 4.156 & High \\
\hline SE1 & Representing has become a habit in my family & 3.500 & High \\
\hline SE2 & The social environment in which I move has & 3.345 & Ordinary \\
\hline
\end{tabular}


Increasing Community Awareness and Intention in Encouraging ...

\begin{tabular}{|c|c|c|c|}
\hline Code & Indicator / Variable & Score & Scale \\
\hline & conditioned someone to waqf & & \\
\hline SE3 & $\begin{array}{l}\text { The recitation group that I follow strongly supports } \\
\text { its members for waqf }\end{array}$ & 3.810 & High \\
\hline \multirow[t]{2}{*}{ SE4 } & $\begin{array}{l}\text { Active in social activities is more likely for someone } \\
\text { to waqf }\end{array}$ & 3.964 & High \\
\hline & Social Environment & 3.655 & High \\
\hline AWE1 & $\begin{array}{l}\text { People who carry out cash waqf are based on their } \\
\text { own awareness }\end{array}$ & 4.036 & High \\
\hline AWE2 & $\begin{array}{l}\text { People who carry out cash waqf always follow the } \\
\text { development of cash waqf }\end{array}$ & 3.560 & High \\
\hline AWE3 & $\begin{array}{l}\text { People who carry out cash waqf usually know the } \\
\text { mechanism of cash representation }\end{array}$ & 3.667 & High \\
\hline \multirow[t]{2}{*}{ AWE4 } & $\begin{array}{l}\text { People want to carry out cash waqf because they } \\
\text { know the benefits }\end{array}$ & 4.179 & High \\
\hline & Awareness & 3.861 & High \\
\hline INT1 & I have a great interest in cash waqf & 4.155 & High \\
\hline INT2 & I have high attention to cash waqf & 4.060 & High \\
\hline INT3 & $\begin{array}{l}\text { I always want to be involved in the development of } \\
\text { cash waqf, both directly and indirectly }\end{array}$ & 3.881 & High \\
\hline \multirow[t]{2}{*}{ INT4 } & $\begin{array}{l}\text { Before deciding to carry out cash waqf I know } \\
\text { exactly the benefits }\end{array}$ & 4.131 & High \\
\hline & Intention & 4.057 & High \\
\hline DEC1 & $\begin{array}{l}\text { efore completing cash waqf I will search for } \\
\text { information in advance about it }\end{array}$ & 4.179 & High \\
\hline DEC2 & $\begin{array}{l}\text { I believe that cash waqf is a good alternative to } \\
\text { charity }\end{array}$ & 4.333 & Very high \\
\hline DEC3 & If I have a chance, I will return to cash & 4.250 & Very high \\
\hline \multirow[t]{2}{*}{ DEC4 } & $\begin{array}{l}\text { I believe that the cash waqf that I provide is } \\
\text { managed well }\end{array}$ & 4.083 & High \\
\hline & Decision & 4.211 & Very high \\
\hline
\end{tabular}

Economica: Jurnal Ekonomi Islam - Volume 10, Nomor 1 (2019) 
The promotion of cash waqf felt by waqif was very low. Starting from the socialization, the information media it uses, the ease of getting information, to the appeals from scholars and community leaders. Of all the indicators measured, the socialization of cash waqf had the lowest score, while the ease of getting / accessing information had the highest score in a very low promotional measure. This means that although the promotion of cash waqf is low, the ease of accessing information about cash waqf is still relatively higher than the effort to socialize cash waqf. Ease of access to information is the most important indicator of its value is very reasonable in today's digital era. Internet access, social media and other facilities become a source of information for everyone who wants to know about cash waqf. However, this will not be enough if the cash waqf activists do not make any effort to encourage the promotion of cash waqf to be a massive thing among the public.

Although the ease of information about cash waqf is highest in the promotion indicators, when compared to the overall value it is still in the low category. This means that the ease of accessing information is not followed by the amount of information itself. As seen from the indicator of cash waqf information in various media is very small according to the waqif.

Social environment variables have a high value. The activity of waqif in social activities is the biggest indicator that allows someone to make a cash waqf. While the family's social environment and recitation also contribute highly after being active in social activities. The workplace and the environment are considered normal in encouraging someone to make a cash waqf.

All indicators of measuring the understanding of waqif are high and very high. Existing indicators include knowledge and understanding of laws, procedures, uses, benefits and impacts of cash waqf for individuals and the community. Waqif believes that cash waqf is an alternative to Islamic philanthropy in reducing poverty. This is indicated by the highest score of the 
Increasing Community Awareness and Intention in Encouraging ...

indicators of all indicators. The high indicator of cash waqf as an instrument to reduce poverty shows that waqif has an understanding of the benefits and uses of cash waqf in terms of reducing poverty compared to other waqf or even with other Islamic philanthropic instruments such as zakat, infaq and shadakoh.

Awareness and intention in waqif are in the high category. Judging from the score, waqif intention is higher than the level of awareness. This indicates that the waqif intention does not arise solely from the awareness of cash waqf, but from other factors beyond consciousness. Indicators of awareness contribute relatively the same to each other with the level of variation in scores that are not much different. The same thing is also an indicator of intention. Intention building indicators have relatively similar variations in scores.

As stated above, the decision of the waqif has a score with very high criteria. The biggest contribution of the constituent to the decision variable is the indicator of the waqif belief that the alternative cash waqf is good alms. As it is known that waqf is a form of alms that the reward will never break even though the waqif is gone. In addition, the ease of cash waqf compared to other waqf makes this indicator as the biggest reason someone wants to makes a cash waqf.

After obtaining the results about the size of each observed variable, the next step is to carry out an evaluation process, namely the validity and reliability test of the indicators making up the model. Validity test uses a loading factor size with the provisions that the value must be greater than 0.05 if the indicator is to be valid. The results of the outer output of the PLS model that have been eliminated against invalid indicators can be seen in Table 3. While the model in the form of PLS path diagram itself is presented in Figure 2.

Economica: Jurnal Ekonomi Islam - Volume 10, Nomor 1 (2019) 
Muhammad Iqbal, Prameswara Samofa Nadya, Saripudin, Puji Hadiyati

Table 3. Outer Output of PLS Model

\begin{tabular}{|c|c|c|c|c|c|c|}
\hline \multirow[t]{2}{*}{ Variable } & \multirow[t]{2}{*}{$\begin{array}{l}\text { Indicator } \\
\text { Code }\end{array}$} & \multicolumn{2}{|c|}{$\begin{array}{l}\text { Validitas } \\
\text { Convergent }\end{array}$} & \multirow{2}{*}{$\begin{array}{l}\text { Validitas } \\
\text { Discriminant } \\
\text { Cross } \\
\text { Loading }\end{array}$} & \multicolumn{2}{|l|}{ Reliabilitas } \\
\hline & & $\begin{array}{l}\text { Loading } \\
\text { Factor }\end{array}$ & AVE & & $\begin{array}{l}\text { Cronbach's } \\
\text { Alpha }\end{array}$ & $\begin{array}{l}\text { Composite } \\
\text { Reliability }\end{array}$ \\
\hline \multirow[t]{5}{*}{ PRO } & PRO3 & 0.591 & 0.537 & 0.733 & 0.796 & 0.850 \\
\hline & PRO4 & 0.749 & & & & \\
\hline & PR05 & 0.891 & & & & \\
\hline & PRO6 & 0.716 & & & & \\
\hline & PR07 & 0.682 & & & & \\
\hline \multirow[t]{5}{*}{ UND } & UND3 & 0.820 & 0.785 & 0.886 & 0.931 & 0.948 \\
\hline & UND4 & 0.909 & & & & \\
\hline & UND5 & 0.914 & & & & \\
\hline & UND6 & 0.949 & & & & \\
\hline & UND7 & 0.831 & & & & \\
\hline \multirow[t]{4}{*}{ SE } & SE1 & 0.649 & 0.526 & 0.726 & 0.704 & 0.816 \\
\hline & SE2 & 0.750 & & & & \\
\hline & SE3 & 0.764 & & & & \\
\hline & SE4 & 0.734 & & & & \\
\hline \multirow[t]{4}{*}{ AWE } & AWE1 & 0.682 & 0.514 & 0.717 & 0.687 & 0.808 \\
\hline & AWE2 & 0.767 & & & & \\
\hline & AWE3 & 0.703 & & & & \\
\hline & AWE4 & 0.712 & & & & \\
\hline \multirow[t]{3}{*}{ INT } & INT1 & 0.886 & 0.738 & 0.859 & 0.822 & 0.894 \\
\hline & INT2 & 0.864 & & & & \\
\hline & INT3 & 0.826 & & & & \\
\hline \multirow[t]{4}{*}{ DEC } & DEC1 & 0.689 & 0.584 & 0.764 & 0.758 & 0.847 \\
\hline & DEC2 & 0.908 & & & & \\
\hline & DEC3 & 0.776 & & & & \\
\hline & DEC4 & 0.660 & & & & \\
\hline
\end{tabular}


The evaluation results are carried out as a whole for the PLS model with two evaluations, the outer model and the inner model. Validity test is done with two approaches, namely convergent validity and discriminant validity. The convergent validity test results with loading factors indicate there is no longer a value below 0.05 so that all indicators are said to be valid. As for the Average Variance Extracted (AVE), all variables are above 0.5, which is the lower limit of the requirements. Discriminant validity test with crossing loading requires all variables above 0.7 and all variables have been fulfilled. So all validity tests have been met both in terms of convergent validity and discriminant validity.

The reliability test used two approaches, namely Cronbach's alpha and composite reliability. Cronbach's alpha test results require all variables to be of at least 0.6. As for the test of reliability, the lower limit of each variable is at least 0.6. Only the awareness variable has a low Cronbach's alpha value of 0.687 but it is still within the tolerance range. As for composite reliability, all variables are above 0.8 , so all variables are declared reliable.

Figure 2. Model of PLS Path Diagram

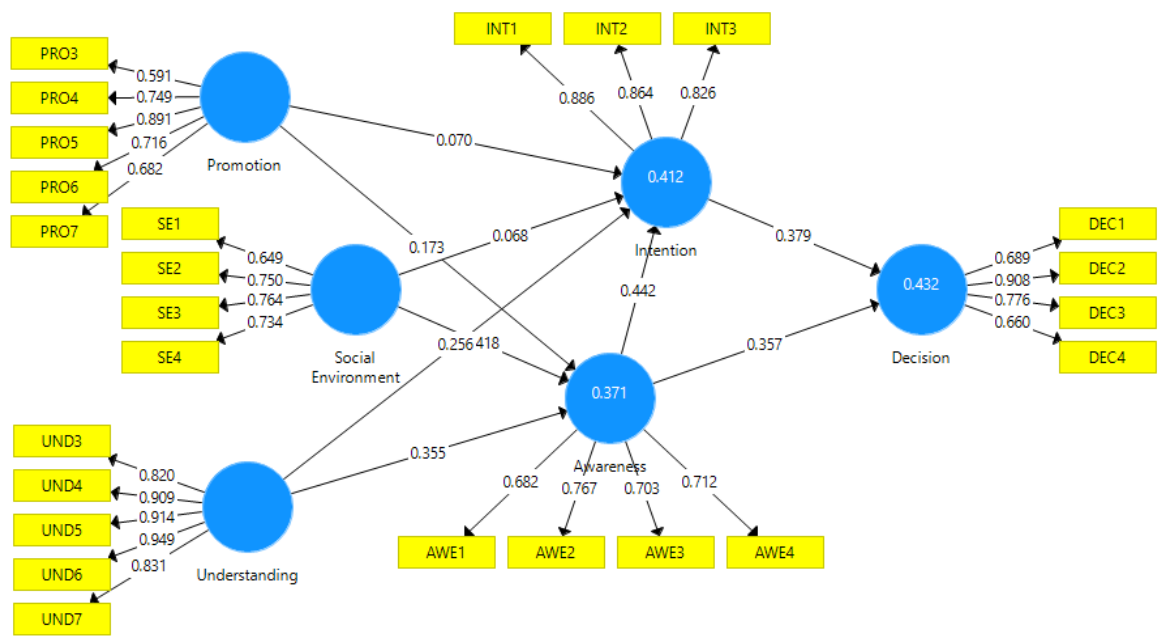

Economica: Jurnal Ekonomi Islam - Volume 10, Nomor 1 (2019) http://journal.walisongo.ac.id/index.php/economica 
As shown in Figure 2, the whole model has three endogenous variables meaning it is divided into three models and has three R-Square values. The three R-Square values are between 0.33 to 0.67 so all three are included in the moderate model category. So it can be concluded that the model formed is included in the moderate model category. Although the model formed is not included in the strong category, at least the model is not included in the weak category, so the model formed can still be used to explain the effect of the relationship between exogenous and endogenous variables. The complete results of the final inner model can be seen in Table 4 .

The significance test of the exogenous promotion variable to the two endogenous variables of awareness and intention has a very small $t$-stat value of 1.231 and 0.717 . Both t-stat values are smaller than the significance limit of 1.96 so it can be said that promotion does not affect awareness or interest. It was also shown by the second p-value both of which were greater than 0.05 . Unlike the promotion variable, the social environment variable has a t-stat value greater than 1.96 for its effect on the awareness variable and smaller than 1.96 for its influence on the variable of intention. This shows that the social environment has a significant effect on awareness but does not affect intention. Significance test results between variables that did not have a significant effect only occurred for these two variables, while the other variables all had a significant effect.

Table 4. Inner Output of PLS Model

\begin{tabular}{llllll}
\hline & & F-Square & Path Coef. & t-stat. & $\boldsymbol{p}$-value \\
\hline Promotion & ' Awareness & 0.047 & 0.173 & 1.231 & 0.219 \\
\hline Promotion & $\cdot$ Intention & 0.008 & 0.070 & 0.717 & 0.474 \\
\hline $\begin{array}{l}\text { Social } \\
\text { Environment }\end{array}$ & ' Awareness & 0.267 & 0.418 & 4.466 & 0.000 \\
\hline $\begin{array}{l}\text { Social } \\
\text { Environment }\end{array}$ & ' Intention & 0.006 & 0.068 & 0.445 & 0.657 \\
\hline Understanding & & & & & \\
\hline
\end{tabular}


Increasing Community Awareness and Intention in Encouraging ...

\begin{tabular}{llllll}
\hline & & F-Square & Path Coef. & t-stat. & $\boldsymbol{p}$-value \\
\hline Understanding & $\cdot$ Intention & 0.090 & 0.256 & 2.622 & 0.009 \\
\hline Awareness & $\cdot$ Intention & 0.209 & 0.442 & 3.875 & 0.000 \\
\hline Awareness & ' Decision & 0.145 & 0.357 & 2.411 & 0.016 \\
\hline Intention & ' Decision & 0.163 & 0.379 & 2.781 & 0.006 \\
\hline
\end{tabular}

Understanding has a significant influence on awareness and intention, as indicated by the value of t-stat and p-value for the influence of both. Similarly, the effect of awareness of intention and decisions has a t-stat value above 1.96 and a p-value below 0.05 so that awareness has a significant effect on intention and decisions. The last relationship that indicated a significant effect was the variable of intention to the decision variable, with a p-value of 0.006 .

Based on the inner model output, it can be seen that promotion does not significantly influence awareness and intention. This shows that the promotion of cash waqf does not raise public awareness of cash waqf. Promotion of the existing cash waqf also does not make people interested to makes cash waqf. Promotion is one of the ways carried out in socializing cash waqf, including conveying information about cash waqf. This result is contrary to the findings of Adeyemi et al., (2016) which states that information about the cash waqf affects the awareness of the public to cash waqf. This result is also different from the findings of Harun et al., (2016) which states that the promotion method affects the awareness of people to cash waqf.

Influence of promotion of intention is strengthened by f-square values less than 0.02 . While the f-square value of promotion to awareness 0.047 is classified as low or can be said to be of little effect. Because of the small effect, the promotion does not affect awareness. The small influence of promotion on awareness is caused by the low level of socialization activities carried out. 
If seen from the measured score about the promotion of cash waqf its value is very low with the lowest contribution contributed by the dissemination of cash waqf in the community.

The lack of massive promotion of cash waqf in the community shows that waqf is not yet a program that has special attention considering that cash waqf itself is only part of the overall waqf program. Even though the waqf program is not only limited to cash waqf. In addition, when compared to other Islamic philanthropic programs, such as zakat, waqf are not required in religion. So to promote it can not be done using a coercive approach as zakat. The persuasive approach is one thing that can be done continuously to foster public awareness of cash money.

The social environment of the community has a significant influence on the awareness of cash waqf. Among all the effects of exogenous variables on endogenous variables, the influence of the social environment on awareness has the highest influence, but when viewed from the f-square the effect is only included in the middle category. The social environment is formed from the family, community environment, worship environment and social activity environment. Those who live in a social environment that is conducive to social activities will tend to have a high awareness of cash waqf. The more conducive to one's social environment, the higher the awareness of cash waqf, while someone whose environment is far from social activities will lower the awareness of cash waqf.

The results of this study are in line with research by Adeyemi et al. (2016) which states that the social environment influences one's awareness about cash waqf. The formation of awareness of the cash waqf can be done by growing religious social communities in which promoting Islamic philanthropic activities such as zakat, infaq, sadaqah and waqf. The formation of a social community can color the environment in which ultimately the family environment. The family environment that is close to individual activities also helps to stimulate one's awareness in making cash waqf. 
Understanding has a significant effect on awareness, this is supported by research by Adeyemi et al. (2016) dan Yunimar (2015). The higher one's understanding of cash waqf, the higher the awareness of cash waqf, and vice versa, a low understanding of cash waqf will reduce one's awareness of cash waqf. In addition to the social environment, awareness can also be built from one's understanding gained from one's knowledge of the cash waqf. Good knowledge of cash waqf will foster a complete understanding of cash waqf. Knowledge of cash waqf includes the existence of cash waqf in Islam, the procedure of cash waqf to the benefits and uses of cash waqf. Complete knowledge about the cash waqf becomes a contributing factor to one's understanding of the cash waqf which later affects the person's awareness of the cash waqf.

Understanding as one of the factors in fostering awareness and intention towards cash waqf provides lessons for us to continue to encourage the community to always learn. The learning process can be done formally or informally. Formally the process of understanding that departs from knowledge is built from elementary, middle to high school. While informally understanding cash waqf can be done on Islamic study activities. Adding the waqf curriculum in religious studies at the school level and making courses in tertiary institutions a way of encouraging people to understand cash waqf. Inviting scholars and community leaders to always educate the public about the benefits and uses of cash waqf can also be done to understand the community so that immediately awareness about cash waqf is formed in the community.

High awareness of cash waqf will foster an intention to do cash waqf. Vice versa, lack of awareness of cash waqf will not encourage someone's intention to make cash waqf. This is the implication of the influence of one's awareness of the intention to make cash waqf. Target also influences the decision to cash waqf. The higher one's awareness of cash waqf, the greater 
the person's decision to cash waqf. Vice versa, low awareness about cash waqf will reduce the possibility of the person to cash waqf.

The influence of the social environment on awareness and the influence of awareness on intentions indicate that awareness mediates the social environment on intentions. In addition, this is also strengthened not affect the social environment of intentions. This means that there is no direct influence from the social environment on intentions, but rather there is an indirect influence from the social environment on intentions mediated by consciousness.

When viewed in the model, awareness also has the possibility as an intervening variable for understanding intention. But because the direct effect of understanding the intention is greater than the indirect effect, awareness is not enough evidence to be an intervening variable. That is, one's understanding of cash waqf can immediately foster interest in making cash waqf, without having to appear awareness or can also be interpreted by the emergence of one's understanding of cash waqf will foster awareness and intention simultaneously.

The final influence not yet explained is the relationship between intention and awareness of decisions. Intention and awareness have a positive effect on decisions. The higher one's intention and awareness of cash waqf will foster a sense of wanting to do cash waqf higher. The same thing happens on the contrary, the more lack of intention and low awareness of someone towards cash waqf, the less likely that person is to make a cash waqf.

Although awareness influences decisions and intention influences decisions, intention does not mediate awareness of decisions. This is evidenced by the smaller indirect effect of consciousness compared to the direct effect. This means that a person's decision to cash waqf can arise from intention and awareness simultaneously. 
Increasing Community Awareness and Intention in Encouraging ...

From the existing model it can be seen that the variable of awareness and intention can act as intervening variables to the three exogenous variables, namely: promotion, social environment and understanding. But because only the social environment and understanding have a significant effect on awareness and intention, only both of them are mediated by awareness and intention in the decision making process towards cash waqf.

This shows that the effort to encourage people to do cash waqf requires a long process. Because it must be preceded by a social environment and a good understanding in advance of cash waqf, after that awareness and intention to make a cash waqf will appear, then there will be a decision to cash waqf. Establishing a social environment that is conducive to fostering a spirit of cash waqf is not an easy matter. In addition to many alternative waqf, many other alternative social activities that can be said to have similarities with cash waqf. Extra efforts are needed to familiarize the public with the existence of cash waqf that is designed in such a way through the efforts to establish a social environment and public understanding of cash waqf.

Not influencing the promotion of the decision to make a cash waqf does not mean there is no need for promotional activities. Promotional activities still need to be carried out by means of intensive and continuous socialization through the formation of the social environment of the community and also socialization in educational programs both formal and non-formal. In the short term, socialization can be done by including understanding cash waqf in the discussion of Islamic studies and also seminars on cash waqf or similar programs. So understanding and social environment can be formed simultaneously. 


\section{Conclusion}

A person's social environment and understanding influence that person to make a cash waqf. The more conducive to one's social environment and understanding, the greater the person decides to make a cash waqf. A person's social environment and good understanding will foster awareness and intention about cash waqf, which in turn will encourage that person to cash waqf.

Based on the results obtained it appears that one's understanding plays an important role in the decision to cash waqf. This should be the basis for encouraging the community to take an active role in raising cash waqf funds. Providing complete information about cash waqf is the first way to understand someone, which of course must be done continuously in a comprehensive program. Growing good knowledge about cash waqf can be done using formal and informal education facilities. Formally, incorporating knowledge about cash waqf in a variety of subjects or courses in higher education should be done in a structured manner, not just limited to appeals. The government can incorporate the discussion of cash waqf into the school curriculum or open a waqf study program or at least the concentration of waqf which includes a lot of discussion about cash waqf.

Forming a social environment can be started from the activities of Islamic studies in which discussing about cash waqf specifically more specifically the benefits and uses. The discussion should not only be limited to law or ushul fiqh, but rather emphasizes the method of making cash waqf, its benefits and uses. Optimizing the existing amil zakat and waqf institutions should be made partners in shaping a conducive social environment and encouraging public understanding of cash waqf. 
Increasing Community Awareness and Intention in Encouraging ...

\section{References}

Adeyemi, A. A., Ismail, N. A., \& Hassan, S. S. B. (2016). An Empirical Investigation of the Determinants of Cash Waqf Awareness in Malaysia. Intellectual Discourse, 24(Special Issue), 501-520.

Aziz, M. R. Ab., \& Yusof, M. A. (2014). Examining the Relationship between Level of Income and Appointment of Agent in Collecting Waqf Fund. International Journal of Trade, Economics and Finance, 5(2), 167-169. https://doi.org/10.7763/IJTEF.2014.V5.363

Chin, W., \& Newsted, P. R. (1999). Structural Equation Modeling Analysis with Small Samples Using Partial Least Square. Statistical Strategies for Small Sample Research.

Creswell, J. W. (2013). Research Design: Qualitative, Quantitative, and Mixed Methods Approaches, 4th Edition (4th edition). Thousand Oaks: SAGE Publications, Inc.

Dahlan, R. (2014). Faktor-faktor Yang Memengaruhi Persepsi Nazhir Terhadap Wakaf Uang. Al-Iqtishad: Jurnal Ilmu Ekonomi Syariah, 6(2), 305-315. https://doi.org/10.15408/aiq.v6i2.1237

Efrizon, A. (2008). Faktor-faktor yang Mempengaruhi Waqif Tentang Wakaf Uang (Tesis). Universitas Indonesia, Jakarta.

Fadhilah, U. N., \& Aminah, A. N. (2018, October 16). Potensi Wakaf Tunai Capai Rp 180 Triliun. Retrieved May 12, 2019, from Republika Online website: https://republika.co.id/share/pgovmd384

Fanani, M. (2011). Pengelolaan Wakaf Tunai. Walisongo: Jurnal Penelitian Sosial Keagamaan, 19(1), 179-196. https://doi.org/10.21580/ws.19.1.217

Fatah, N. S. A., Mansor, N., Ripain, N., \& Endut, W. A. (2017). Waqf Participation And Awareness: An Exploratory Study In The West Coast Of Sabah, Malaysia. International Journal of Research Science and Management, 4(6), 50-58. https://doi.org/10.5281/zenodo.583973

Furqon, A. (2011). Analisis Praktek Perwakafan Uang pada Lembaga Keuangan Syariah. Walisongo: Jurnal Penelitian Sosial Keagamaan, 19(1), 157-178. https://doi.org/10.21580/ws.19.1.216

Economica: Jurnal Ekonomi Islam - Volume 10, Nomor 1 (2019) 
Muhammad Iqbal, Prameswara Samofa Nadya, Saripudin, Puji Hadiyati

Ghozali, I., \& Latan, H. (2015). Partial Least Squares Konsep, Teknik dan Aplikasi Menggunakan Program SmartPLS 3.0 Untuk Penelitian Empiris (2nd ed.). Semarang: Badan Penerbit Universitas Diponegoro.

Harun, R., Rashid, R. A., Murat, A., \& Yaakub, N. I. (2016). Promotion as a Determinants for Waqf Awareness Among University. International Academic Research Journal of Social Science, 2(1), 95-99.

Haryanto, R. (2013). Pengentasan Kemiskinan Melalui Pendekatan Wakaf Tunai. Al-Ihkam: Jurnal Hukum \& Pranata Sosial, 7(1), 178-200. https://doi.org/10.19105/al-ihkam.v7i1.323

Hasan, S. (2010). Wakaf Uang dan Implementasinya di Indonesia. Journal de Jure, 2(2), 162-177.

Hasan, S., \& Rahmawati, N. (2011). Wakaf Uang: Perspektif Fiqih, Hukum Positif, dan Manajemen. Malang: UIN-Maliki Press

Hastuti, Q. 'Aini W. (2018). PERAN LEMBAGA KEUANGAN SYARIAH PENERIMA WAKAF UANG (LKS-PWU) BAGI OPTIMALISASI WAKAF UANG. ZISWAF: Jurnal Zakat Dan Wakaf, 4(1), 41-54. https://doi.org/10.21043/ziswaf.v4i1.3030

Huda, N., Rini, N., Mardoni, Y., Hudori, K., \& Anggraini, D. (2017). Problems, Solutions and Strategies Priority for Waqf in Indonesia. Journal of Economic Cooperation and Development, 38(1), 29-54.

Ibrahim, H., Amir, A., \& Masron, T. A. (2013). Cash Waqf: An Innovative Instrument for Economic Development. International Review of Social Sciences and Humanities, 6(1), 1-7.

Ilyas, S. (2014). Perkembangan Perwakafan di Kota Batam. Jurnal Bimas Islam, 7(4), 783-795.

Kasdi, A. (2016). Pergeseran Makna dan Pemberdayaan Wakaf. ZISWAF: Jurnal Zakat Dan Wakaf, 3(1), 1-17.

Kotler, P. T., \& Keller, K. L. (2015). Marketing Management (15 edition). Boston: Pearson.

McMillan, J. H., \& Schumacher, S. (2009). Research in Education: EvidenceBased Inquiry (7 edition). Boston: Pearson.

Mohsin, M. I. A. (2013). Financing through cash-waqf: a revitalization to finance different needs. International Journal of Islamic and Middle Eastern Finance and Management; Bingley, 6(4), 304-321. 
Increasing Community Awareness and Intention in Encouraging ...

Mu'alim, M., \& Abdurrahman. (2014). Menggiatkan Wakaf Uang (Tunai) sebagai Upaya Peningkatan Kesejahteraan Masyarakat. Jurnal Bimas Islam, 7(4), 727-754.

Mulyono, D. (2016). Pengaruh Media Sosial Terhadap Keputusan Memberikan Donasi Pada Rumah Zakat (Tesis). Institute Pertanian Bogor, Bogor.

Muntaqo, F. (2015). Problematika dan Prospek Wakaf Produktif di Indonesia. Al-Ahkam, 1(25), 83-108. https://doi.org/10.21580/ahkam.2015.1.25.195

Nilna Fauzah. (2015). Rekonstruksi Pengelolaan Wakaf: Belajar Pengelolaan Wakaf dari Bangladesh dan Malaysia. Universum : Jurnal KeIslaman Dan Kebudayaan, 9(2), 161-171.

Rahmawati, Y. (2013). Persepsi Waqif dalam Berwakaf Tunai. Al-Iqtishad: Journal Ilmu Ekonomi Syariah, 5(1), 97-116. https://doi.org/10.15408/aiq.v5i1.2558

Sekaran, U., \& Bougie, R. (2013). Research Methods for Business: A SkillBuilding Approach (6 edition). Chichester, West Sussex: Wiley.

Siswantoro, D., \& Rosdiana, H. (2016). Sustainability of Cash Waqf Development in Indonesia: A Quintuple Helix Perspective. Sains Humanika, 8(1-2), 111-116. https://doi.org/10.11113/sh.v8n1-2.840

Syafiq, A. (2016). Wakaf Tunai untuk Pemberdayaan Usaha Kecil. ZISWAF: Jurnal Zakat Dan Wakaf, 1(2), 1-25.

Syamsir, R. (2015). The Economic Empowerment of the Ummah on the Basis of Productive Waqf in West Sumatra, Indonesia. International Journal of Nusantara Islam, 3(1), 31-46. https://doi.org/10.15575/ijni.v3i1.314

Uyun, Q. (2015). Zakat, Infaq, Shadaqah dan Wakaf Sebagai Konfigurasi Filantropi Islam. ISLAMUNA: Jurnal Studi Islam, 2(2), 218-234. https://doi.org/10.19105/islamuna.v2i2.663

Wold, H. (1982). Soft modeling: the basic design and some extensions. Systems under Indirect Observation : Causality, Structure, Prediction, 2, 154.

Yunimar, M. (2015). Tingkat Pemahaman Mahasiswa Universitas Islam Negeri Syarif Hidayatullah Jakarta Terhadap Wakaf Uang (Sripsi). UIN Syarif Hidayatullah, Jakarta.

Economica: Jurnal Ekonomi Islam - Volume 10, Nomor 1 (2019) 
